\title{
Food and Feeding Biology of Brackish Water Fish Epinephelus diacanthus along the South Konkan Coast of Maharashtra, India
}

\author{
L.S. Uskelwar ${ }^{1 *}$, M.S. Sawant ${ }^{1}$, R.A. Pawar ${ }^{1}$, V.H. Nirmale ${ }^{1}$, \\ A.S. Pawase ${ }^{1}$ and S.Y. Metar ${ }^{2}$ \\ ${ }^{1}$ College of Fisheries, Ratnagiri, India \\ ${ }^{2}$ Marine Biological Research Station, Ratnagiri, Dr. B.S. Konkan Krishi Vidyapeeth, \\ Dapoli, Maharashtra, India \\ *Corresponding author
}

\begin{abstract}
A B S T R A C T
\section{Keywords}

Epinephelusdiacant hus, Diet, Feeding,

Feeding intensity

\section{Article Info}

Accepted:

24 November 2018

Available Online:

10 December 2018

The Spinycheek grouper (Epinephelus diacanthus) is a marine species usually associated with rocky bottoms and reefs. Groupers are one of the most important carnivorous fishes of coral reefs, feeding mainly on the crustaceans and fishes. The present study revealed the food and feeding biology of Epinephelus diacanthus collected from the South Konkan coast of Maharashtra. The percentage of dietary concentration and feeding intensity was investigated from October 2017 up to June 2018 The results were promising and revealed the information on the food consumption of fishes in the study area and helped to understand the fish's feeding biology.
\end{abstract}

\section{Introduction}

The spiny cheek grouper, Epinephelus diacanthus (Valenciennes, 1828) is a demersal species belonging to the family Serranidae, which are commonly known as groupers, rockcods, and hamours, a group of percoid fishes in the order Perciformes. It is distributed on the continental shelf of the north-western Indian Ocean from the Gulf of Aden to Sri Lanka and Madras (India), but is not known from the Persian Gulf or the Red Sea (Heemstra and Randall, 1993), and in the eastern Indian Ocean off Thailand (Chen et al., 1980; Monkolprasit et al., 1997) and Hong
Kong (Ni and Kwok, 1999). In Omani waters, the spinycheek grouper occurs on mud and muddy sand bottom from very shallow waters of about $2 \mathrm{~m}$ deep down to $110 \mathrm{~m}$ (Abdelsalaam 1995). Knowledge on food and feeding biology which provide insight into feeding habit will help in devising appropriate management measures for the fishery. Similarly within the context of high culture potential of $E$. dicanthus in India understanding its biology is vital.

\section{Materials and Methods}

E. diacanthus samples were collected from the Harnai, Ratnagiri, Purngad, Vijaydurg, 
Malven and vengurla fish market at monthly interval and were brought to the laboratory for analysis. The present study is based on the total of 362 individuals ranging in the size range from 80 to $190 \mathrm{~mm}$ total length (TL). Qualitative analysis was done as per the procedure given by (Hyslope 1980). Quantitative analysis was carried out by using gravimetric methods method. The gravimetric method consists of the estimation of the weight of each of the food items, which is usually expressed as percentages of the weight of the total gut contents as in other quantitative methods. The number of each item was recorded and expressed as a percentage of the total number of all food items in the sample studied.

\section{Results and Discussion}

\section{Food composition}

The gut content analysis indicated that crab, fishes, shrimps items formed the main food items of the species. The average proportion of the gut contents for the entire study period was crab (37.39\%), fishes $(31.88 \%)$, and shrimps $(30.37 \%)$. It is mentioned in Table 1.

\section{Food composition in various months}

Month wise composition of food items is presented in Table 2 and Figure 1. Crab were observed in all months with peak in October $(62.16 \%)$ followed by June (57.21\%), November $(56.21 \%)$ and the lowest quantity was found during February $(22.15 \%)$. Fishes were recorded in all the months with peak in October (44.21\%) followed by January $(37.45 \%)$ and November (35.42\%). The lowest quantity was noted during June $(22.95 \%)$. Shrimps were observed in all the months with peak abundance in October (52.51\%), followed by November (42.52\%), April (35.54\%). The lowest quantity was found during May (21.45\%).

\section{Food composition in various size groups}

Percentage composition of various food items in the stomach contents by gravimetric method of $E$. diacanthus in various size groups are given in the Table 3. Crabs were noted almost in all size groups of fishes. The maximum percentage was found in the size group 90-100 $\mathrm{mm}(36.32 \%)$ followed by $70-180 \mathrm{~mm}$ $(29.23 \%)$ and $100-110 \mathrm{~mm}(28.75 \%)$ and lowest in the size groups of $80-90 \mathrm{~mm}$ $(18.75 \%)$. The highest percentage of fishes was observed in the size group 180-190 mm $(45.08 \%)$ while the lowest was noted in size group 90-100 $\mathrm{mm}$ (22.32\%). Maximum amount of shrimps were encountered highest in the size group $140-150 \mathrm{~mm}(33.89 \%)$ and lowest in the size group 150-160 $\mathrm{mm}$ (14.49\%).

\section{Feeding intensity}

Monthly variations in the fullness of stomach in E. diacanthus are given in Table 4 and Figure 2. During the entire study period, $17.26 \%$ of the stomachs were noted to be full, $15.32 \%$ were three quarter full, $20.80 \%$ stomach were half occupied, $17.62 \%$ were occupied up to a quarter and $28.99 \%$ were empty stomachs. The highest percentage of full stomachs were deserved in June (35.75\%) and November (23.65\%). Maximum number of three quarter full stomachs were found in November (22.46\%) and half-full stomachs in October $(35.26 \%)$. November recorded the highest percentage of one quarter full stomachs. While more empty stomachs were found in February (45.20\%).

The present observation on the qualitative and quantitative nature of the stomach contents suggests that $E$. diacanthus feed mainly on crab (37.39\%), fishes (31.88\%), and shrimps $(30.37 \%)$. The present study revealed that $E$. diacanthus is a carnivorous feeder. 
Table.1 Food composition of E. dicanthus during the study period

\begin{tabular}{|l|r|}
\hline Food Items & Percentage \\
\hline Crab & 37.39 \\
\hline Fishes & 31.88 \\
\hline Shrimps & 30.73 \\
\hline
\end{tabular}

Table.2 Percentage composition of food items in the stomach of E. dicanthus from October 2017 to June 2018

\begin{tabular}{|c|c|c|c|c|c|c|c|c|c|}
\hline Food Items & October & November & December & January & February & March & April & May & June \\
\hline Crab & 62.16 & 56.21 & 28.21 & 31.19 & 22.15 & 23.07 & 25.04 & 31.26 & 57.21 \\
\hline Fishes & 44.21 & 35.42 & 29.15 & 37.45 & 32.38 & 24.44 & 34.15 & 26.78 & 22.95 \\
\hline Shrimps & 52.51 & 42.52 & 26.00 & 22.41 & 26.65 & 24.48 & 35.54 & 21.45 & 25.00 \\
\hline
\end{tabular}

Table.3 Percentage composition of food items in the stomachs of E. dicanthus in various size groups from Oct. 2017 to Jun. 2018

\begin{tabular}{|l|r|r|r|}
\hline $\begin{array}{l}\text { Size groups in }(\mathbf{c m}) \\
\text { TL }\end{array}$ & Crab & Fishes & Shrimps \\
\hline $\mathbf{8 0 - 9 0}$ & 18.75 & 41.16 & 15.54 \\
\hline $\mathbf{9 0 - 1 0 0}$ & 36.32 & 22.32 & 22.73 \\
\hline $\mathbf{1 0 0}-110$ & 28.75 & 33.82 & 19.45 \\
\hline $\mathbf{1 1 0}-120$ & 21.80 & 36.78 & 26.64 \\
\hline $\mathbf{1 2 0}-130$ & 21.58 & 25.79 & 31.58 \\
\hline $\mathbf{1 3 0}-140$ & 20.42 & 22.53 & 32.00 \\
\hline $\mathbf{1 4 0 - 1 5 0}$ & 21.67 & 27.98 & 33.89 \\
\hline $\mathbf{1 5 0}-160$ & 25.45 & 42.00 & 14.49 \\
\hline $\mathbf{1 6 0 - 1 7 0}$ & 22.41 & 42.73 & 18.95 \\
\hline $\mathbf{1 7 0 - 1 8 0}$ & 29.23 & 35.15 & 18.39 \\
\hline $\mathbf{1 8 0 - 1 9 0}$ & 19.68 & 45.08 & 18.79 \\
\hline
\end{tabular}

Table.4 Month wise distribution of degree of feeding intensity of $E$. dicanthus

\begin{tabular}{|c|c|c|c|c|c|}
\hline Month & Full \% & $\mathbf{3 / 4} \%$ & $\mathbf{1 / 2} \%$ & $\mathbf{1 / 4} \%$ & Empty \% \\
\hline October & 22.94 & 11.57 & 35.26 & 27.15 & 40.12 \\
\hline November & 23.65 & 22.46 & 28.31 & 31.28 & 36.21 \\
\hline December & 11.27 & 14.25 & 13.22 & 12.41 & 23.28 \\
\hline January & 12.04 & 15.45 & 15.45 & 15.20 & 15.35 \\
\hline February & 11.45 & 14.12 & 17.23 & 13.58 & 45.20 \\
\hline March & 13.47 & 12.25 & 15.68 & 12.01 & 40.10 \\
\hline April & 11.24 & 17.86 & 18.45 & 11.24 & 28.15 \\
\hline May & 13.55 & 13.28 & 16.55 & 14.25 & 16.00 \\
\hline Jun & 35.75 & 16.65 & 27.05 & 21.46 & 16.52 \\
\hline
\end{tabular}


Fig.1 Food composition in various months

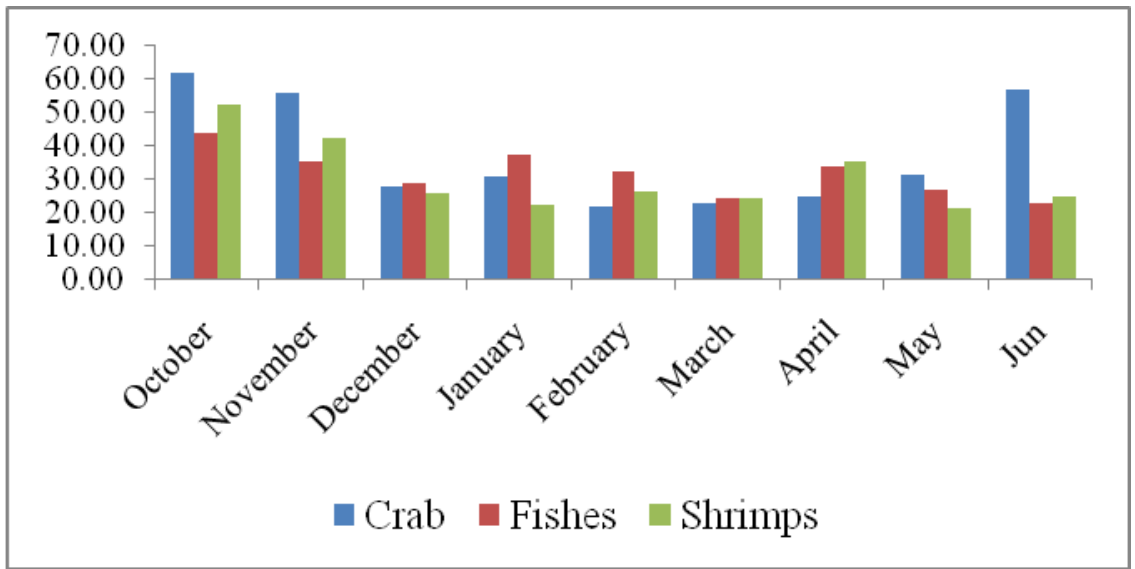

Fig.2 Feeding intensity

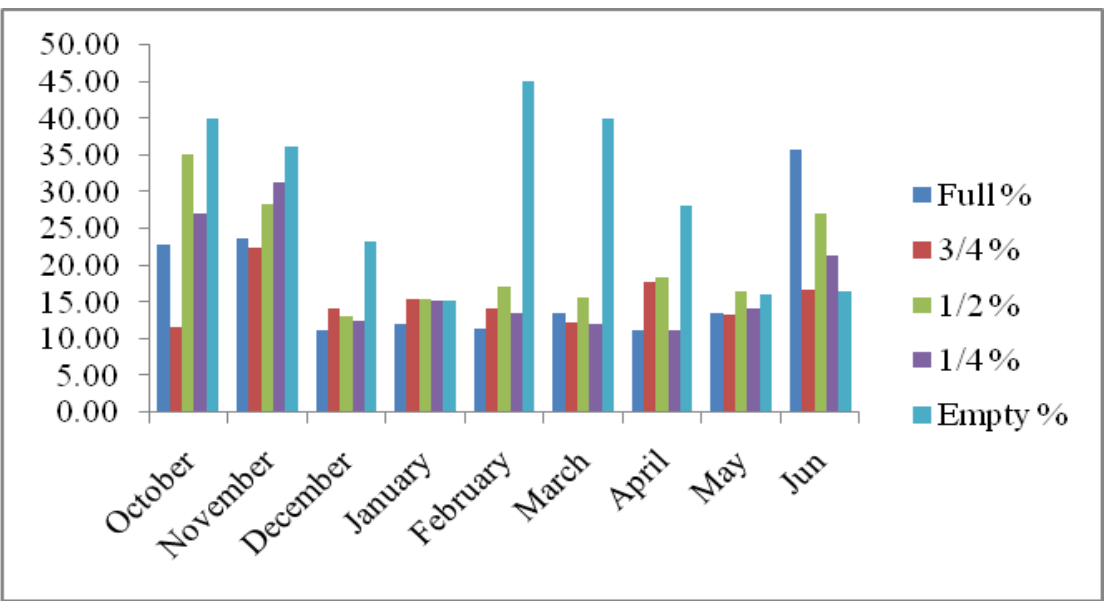

The food of E. diacanthus was dominated by crabs, fishes and shrimps. It indicated that those species were available abundantly throughout the season. E. diacanthus is a demersel fish in the South West Coast of India, which prefers to life on rocky habitats and as such they are abundant in the Wadge Bank, Quilon Bank and Gulf of Mannar. Here the sea bottom is mostly rocky without crops of rocks farming ideal habitats for grouper.

Major food items for E. diacanthus were reported to be crabs, fishes and shrimps during most of the months. As Smith (1961) observed in other groupers, E. diacanthus also swallows its food without chewing it and so it was fairly easy to identify the organisms present in the fish feeds by Sight Job (1940) observed that even the disposition of the mouth of perches like E. tauvinais more suited for browsing and pecking off food from the ground. Premalatha (1989) studied the food habits of E. aereolatus, E. chlorostigma, E. bleekeri and E. diacanthus and reported that the diet composition of E.aereolatus was mainly small crustaceans; fish scales and cuttle bones were also met with in them.

In the present study of $E$. diacanthus consumed size groups the crabs ranged from 90 to $180 \mathrm{~mm}$ size groups. Fishes were found in sizes which ranged from 90 to $190 \mathrm{~mm}$ size groups. Shrimps were about 140 to $160 \mathrm{~mm}$ size groups respectively. The highest percentage of full 
stomachs in $E$. diacanthus was noted during the month of June, October and November in the present study. The highest percentage of empty stomachs was seen in the month of October to February. Investigations on the food and feeding habits will throw more light on the migratory and shoaling habits of pelagic species of fish and it is particularly important for a species of high commercial value such as the grouper.

It is concluded that $E$. diacanthus is a carnivore mainly feeding on crabs, fishes and shrimps.

\section{Acknowledgement}

Authors are grateful to the authorities of Dr. B.S. Konkan Krishi Vidyapeeth, Dapoli, Dist. Ratnagiri (Maharashtra) for providing facilities to carry out this work.

\section{References}

Abdessalaam, T.Z.S. (1995). Marine species of the Sultanate Oman: An identification guide. Ministry of Aquaculture and Fisheries, Marine Science and Fisheries Centre, Sultanate of Oman. Muscat Printing Press, $412 \mathrm{pp}$.

Al-Marzouqi, et al., (2015). Some aspects on distribution and biology of spiny cheek grouper Epinephelus diacanthus (Valenciennes), from the Arabian sea of Oman. J. Biol. Agri. And Helth.Vol. 5, No. 18.

Badhul Haq et al., (2016). Food and feeding biology of fish Epinephelus malabaricus of Palk Bay and Gulf of Mannar coastal waters. IJCRM. Vol. 1: 12-19.

Chen, C.P., Hsieh, H.L. and Chang, K.H. (1980a). Age and growth of the grouper, Epinephelus diacanthus (Cuvier et
Valenciensis) in the waters of northern Taiwan. Bulletin of the Institute of Zoology Academia Sinica, 19(1), 1-9.

Heemstra, P.C. and Randall, J.E. (1993).FAO species catalogue. Vol. 16.Groupers of the world (Family Serranidae, Subfamily Epinephelinae). An annotated and illustrated catalogue of the grouper, rockcod, hind, coral grouper and lyretail species known to date. FAO Fisheries Synopsis. No. 125, Vol. 16. Rome, FAO, $382 \mathrm{p}$.

Hyslop, E.J., Stomach content analysis - a review of method and their applications. J. Fish. Biol., 17(1980): 411- 429.

Manojkumar, P. P., (2005). Fishery of the spinycheek grouper, E. diacanthus (Valenciennes), off Calicut along the Malabar Coast. J. Mar. Boil. Ass. India, 47(1): 63-69.

Monkolprasit, S., Sontirat, S., Vimollohakarn S. and Songsirikul T. (1997).Checklist of Fishes in Thailand. Office of Environmental Policy and Planning, Bangkok, Thailand, 353 p.

Ni, I.H. and Kwok, K.Y. (1999).Marine fish fauna in Hong Kong waters. Zool. Stud., 38(2), 130-152.

Premalatha, P., 1989. Fishery and biology of rockcods (Order Perciformes) from the southwest coast of India. Indian Journal of Fisheries. 36(9). pp. 285-291.

Sivakami, S. and Seeth, P. K., (2006). Indescriminate destruction of juveniles of spiny cheek grouper Epinephelus diacanthus (Valenciennes), off Quilon, Kerala. J. Mar. Boil. Ass. India, 48 (1): 128-130.

Smith, C.L., 1961. Synopsis of biological data on groupers (Epinephelus and allied genera) of the Western North Atlantic. FAO. Fisheries Biology Synopsis. 23. pp. 1-30.

\section{How to cite this article:}

Uskelwar, L.S., M.S. Sawant, R.A. Pawar, V.H. Nirmale, A.S. Pawase and Metar, S.Y. 2018. Food and Feeding Biology of Brackish Water Fish Epinephelus diacanthus along the South Konkan Coast of Maharashtra. Int.J.Curr.Microbiol.App.Sci. 7(12): 3106-3110. doi: https://doi.org/10.20546/ijcmas.2018.712.356 